\title{
The Effects of Creative Writing Activities Made With Web 2.0 Tools on the Writing Attitude and Creative Writing Skills of Grade 4 Students
}

\author{
Niymet Demirci \\ Class Education Department, Gazi University, Ankara, Turkey \\ E- Mail: niymetdemirci@gmail.com \\ Yasemin Boyaci Altinay \\ Class Education Department, Gazi University, Ankara, Turkey \\ E- Mail: yaseminbaltinay@gmail.com
}

\begin{abstract}
The use of Web 2.0 tools, which have been developed based on the point the technology has reached today, in creative writing studies is gaining importance. In this study, it was aimed to determine the effect of writing activities using web 2.0 (Voki, Storybird, Little Bird, Story Book) tools on fourth grade students' writing attitudes and writing skills.

In line with the research problems, quantitative research methods, pre-test and post-test, single-group quasi-experimental design were used in the research. The sample of the research consists of 28 students studying in the 4th grade in the district of Askale in Erzurum province in the 2019-2020 academic year. The sample group was formed by purposeful sampling method. The Attitude Towards Writing Scale (YAYTO, 2009) and the Evaluation Criteria Form (YIDOF, 2011) were used as data collection tools by Susar Kirmizi (2009), which aims to determine the attitudes of 4th and 5th grade students towards writing. According to the pre-test and post-test t-test results of the data collected in the research, it was determined that the creative writing activities using the web 2 tools positively affected the writing attitudes of 4 th grade students $(p>0.05)$. In creative writing skills of the students, it was found that the mean of creative writing pre-test scores was 51.96, the mean of post-test scores was 72.28, and according to the results of the T-test, the pre-test and post-test scores differ significantly from each other $(\mathrm{t} 27=-7.46$ and $\mathrm{p}<0,05)$. As a result, it has been revealed that activities performed with web 2.0 tools positively affect the writing attitudes and creative writing skills of 4 th grade students.
\end{abstract}

Keywords: Web 2.0 tools, creative writing, writing attitude

DOI: $10.7176 / J S T R / 7-04-02$

\section{Web 2.0 Araçları İle Yapılan Yaratıcı Yazma Etkinliklerinin 4. Sınıf Öğrencilerinin Yazma Tutumuna Ve Yaratıcı Yazma Becerilerine Etkisi}

\section{Özet}

Teknolojinin günümüze geldiği noktadan hareketle geliştirilen Web 2.0 araçlarının yaratıcı yazma çalışmalarında da kullanımı önem kazanmaktadır. Bu araştırmada web 2.0 (Voki, Storybird, Little Bird, Story Book) araçları kullanılarak yaptırılan yazma etkinliklerinin dördüncü sınıf öğrencilerinin yazmaya yönelik tutumlarına ve yazma becerilerine etkisinin belirlenmesi amaçlanmıştır. Araştırma problemleri doğrultusunda araştırmada nicel araştırma yöntemlerinden ön test ve son test tek gruplu yarı deneysel desen kullanılmıştır. Araştırma örneklemini 2019-2020 Eğitim-Öğretim yılında Erzurum ili Aşkale ilçesinde 4. Sınıfta 
öğrenim gören 28 öğrenci oluşturmaktadır. Örneklem grubu amaçlı örnekleme yöntemi ile oluşturulmuştur. Araştırmada veri toplama araçları olarak Susar Kırmızı (2009) tarafindan 4. ve 5. sınıf öğrencilerin yazmaya yönelik tutumlarını tespit etmeyi hedefleyen Yazmaya Yönelik Tutum Ölçeği (YAYTÖ, 2009) ve Değerlendirme Ölçütleri Formu (YİDÖF, 2011) kullanılmıştır. Araştırmada toplanan verilerin ön test ve son test t-testi sonuçlarına göre web 2 araçları kullanılarak yapılan yaratıcı yazma etkinliklerinin 4. sınıf öğrencilerinin yazma tutumlarını $(p>0,05)$ olumlu yönde etkilediği tespit edilmiştir. Öğrencilerin yaratıcı yazma becerilerinde de yaratıcı yazma ön test puanları ortalamasının 51,96 ve son test puanları ortalamasının 72,28 olduğuna ve T-testi sonucuna göre ön test ve son test puanlarının birbirinden anlamlı olarak farklılık gösterdiğine ulaşılmıştır ( $\mathrm{t} 27=-7,46$ ve $\mathrm{p}<0,05)$. Sonuç olarak web 2.0 araçları ile yapılan etkinliklerin 4. Sınıf öğrencilerinin yazma tutumlarını ve yaratıcı yazma becerilerini olumlu yönde etkilediği ortaya çıkmıştır.

Anahtar Kelimeler: Web 2.0 araçları, yaratıcı yazma, yazma tutumu

\section{Giriş}

Dil, insanların duygu, düşünce ve gözlemlerini işaret ya da kelimelerle paylaştıkları bir sistemdir (Güneş, 2017). Dil aracıllı̆ı ile insanlar arasında iletişim gerçekleşmektedir. Bu nedenle dil becerilerini oluşturan en önemli unsurlardan biri olarak kabul edilen yazma aynı zamanda en önemli iletişim aracı olarak da kabul edilmektedir. Dil öğretiminde de yazma ayrı bir yere ve öneme sahiptir. Yazma Akyol (2018) tarafindan düşüncelerimizi ifade edebilmek için gerekli olan sembol ve işaretlerin motorsal şekilde üretilebilmesi olarak tanımlanmaktadır.

Güneş (2017) ise yazmayı işlem olarak zihnimizde yapılandırılmış duygu, düşünce ve isteklerimizin belli kurallar dâhilinde yazıya aktarılması olarak ifade etmektedir. Akyol (2012) yazma becerisinin birbirini takip eden iki aşamadan meydana geldiğini söylemektedir. Bunlardan birinci aşama kazanım aşamasıdır. Bu aşamada öğrenci öncelikle harf, hece, kelime ve cümlelerin ne olduklarını ve ne şekilde yazıldıklarını öğrenmektedir. İkinci aşama ise bu öğrendiklerinin geliştirildiği aşamadır. Bu aşamada yazma ile ilgili edinmiş olduğu becerileri yazılı anlatımda en doğru ve etkili olarak nasıl kullanabileceğini öğrenmektedir.

Yazma becerisi dil becerilerinden okuma becerisi kadar insan hayatında önemli bir yer tutmaktadır. Göçer (2007), gerek Türkçe derslerinde gerekse diğer derslerde okuduğunu anlama becerisi gibi yazma becerisinin de çok sık kullanılan bir beceri olduğunu dile getirmektedir. Çünkü duygu, düşünce ve hayallerin öğrenciler tarafindan doğru ve anlaşılır bir şekilde ifade edilebilmesi oldukça önemlidir. Coşkun (2009) yazma eğitiminin başlıca amacının metin oluşturmak değil o metni ortaya çıkarabilmek için gerekli olan becerilerin kazandırılması gerektiğini savunmaktadır.

Cresswell (2008) yazma becerisinin alıştırmalar ve tekrarlar yapılarak öğrenme yoluyla geliştirilebileceğini savunmaktadır. Bunun için de öğrencilere duygu, düşünce ve hayallerini doğru ve anlaşılır şekilde ifade etmeleri için eğitim ortamları yaratılması gerektiğini belirtmektedir. Öztürk (2019) eğer öğretmenler yazma süreçlerinin farkında olurlarsa öğrenme öğretme ortamlarında uygun stratejileri kullanarak öğrencilerin yazma becerilerini geliştirebileceklerini belirtmektedir. Aynı zamanda yazma çalışmaları sayesinde öğretmenlerin öğrencilerini tanıyabilme, öğrencilerine düşünme fırsatı vererek bilgilerini gösterme ve derinlemesine düşündürme imkânı verdiğini söylemektedir. Ancak öğrencilere yazma becerileri kazandırmada özellikle küçük yaşlardan itibaren yazmaya karşı olumlu bir tutum geliştirmeleri de önem taşımaktadır. Bu nokta da öğretmenlere büyük sorumluluklar düşmektedir. Öztürk (2019) öğretmenlerin öğrencilerin gerek yazma becerilerini gerekse yazmaya karşı olumlu tutumlarını geliştirebilmek amacıyla yazının dilbilgisi özelliklerinden çok öğrencilerin düşüncelerini, duygularını yazıya etkili bir biçimde aktarmalarına öncelik vermeleri gerektiğinin önemine dikkat çekmektedir. Bu nedenle öğrenme öğretme ortamları öğrencilerin yaratıcı yazma becerilerini geliştirecek şekilde düzenlenmelidir. Göçer (2016) yazma çalışmalarının sadece bazı yazma tekniklerinin olduğu gibi uygulanması demek 
olmadığını, öğrencilerin hayallerinden, yaşantılarından ve izlenimlerinden yola çıkarak ortaya özgün ve yaratıcı ürünler çıkarmak olduğuna dikkat çekmektedir. Aynı zamanda yazma çalışmalarına başlanılmadan önce öğrencilerin nitelikli edebiyat ürünleri ile tanıştırılıp okumaları sağlanmalı okuma açısından belirli bir düzeye geldikten sonra yazma çalışmaları yapılmasının daha etkili ve verimli sonuçlar vereceğini belirtmektedir. Güneş (2017) yazma becerilerinin geliştirilebilmesi için öğrencilerle birtakım çalışmalar yapılması gerektiğini belirtmektedir. Öncelikle öğrencilerin düşüncelerini mantıksal bir bütünlük içinde yazmalarını, değişik düşünmeye yönlendiren ifadelere yer verme, neden-sonuç ilişkileri kurma, sınıflandırma, karşılaştırma, özetleme ve değerlendirme gibi zihinsel becerileri geliştirici ve anlamayı sağlayıcı çalışmalar yapılmasının önemini vurgulamaktadır. Bununla birlikte çeşitli yazma türlerine de yer verilmesi gerektiğini belirtmektedir. Bunlardan 21. yy becerilerinden biri olan yaratıcılığın öğrencilere kazandırılması gereken en önemli yaşam becerilerinden biri olduğu göz önünde bulundurulduğunda duygu, düşünce ve hayallerin özgürce ifade edilmesinde yaratıcı yazmanın ne kadar önemli olduğu gerçeği gözler önüne serilmektedir. Yaratıcı yazmada çocuklar düşüncelerini, duygularını, hayallerini herhangi bir sınırlama getirmeden özgür bir şekilde ifade edebileceklerdir. Aynı zamanda kendilerine özgün bir ürün ortaya çıkardıkları için yazmaya karşı da olumlu tutum geliştirmelerine katkı sağlayabilmektedir( Temizkan, 2014).

Yaratıcı yazmada planlama, düşünce ve organizasyon oldukça önemlidir. Aynı zamanda hayal gücü ve orijinallikle birlikte bireylerin yazma sürecinde ele aldıkları konu da ne kadar özgün olursa ve o konu ile ilgili olarak duygu ve düşüncelerini ne kadar özgürce yazıya aktarırlarsa yazıdaki yaratıcıkları da bir o kadar gelişmiş olacaktır. Rechards (1990) Eğer öğrenciler herhangi bir şekilde sınırlandırılırsa ortaya çıkardıkları ürünün hem özgün olmayacağını hem de yaratıcılıklarının olumsuz etkileneceğini belirtmektedir (Akt., Öztürk, 2019). Brookes ve Marshall (2004) yaratıcı yazmanın düşüncelerdeki doğruluktan ziyade özgünlük ve hayal gücüne bağlı olarak geliştiğini belirtmektedir. Aynı zamanda karşı tarafa bilgi aktarmak değil dili kullanma becerisine bağlı olarak bireysel ifadesi ile düşüncelerini aktarmak olduğunu dile getirmektedir.

Başarılı bir yaratıcı yazma öğretiminde öğretmenlerin önemli görevleri vardır. Öğretmenlerin öncelikle öğrenciler için uygun ortamlar oluşturmaları gerektiğini belirten Gündüz ve Şimşek (2011) yaratıcı yazmada öncelikle öğrencileri sınırlayan engellerin ortadan kaldırılması gerektiğini vurgulamaktadır. Ancak bu şekilde öğrencilerin hayal kurma, cesaret, gözlem yapma, eleştirme gibi duygularını rahatlıkla ortaya koyup açıklayabileceklerini belirtmektedirler. Öğretmenin en önemli görevlerinden biri de öğrencilere en iyi şekilde rehberlik etmek ve öğrencilerin yaratıcılıklarını ortaya koyma konusunda cesaretlendirmektir. Oral (2003) öğrencilerin yaratıcı yazma becerilerinin geliştirilebilmesinde öncülük etmek isteyen öğretmenin öğrencilerin duygu ve düşüncelerine empati kurabilmesi için kendisinin de yaratıcı yazma çalışmaları yapmasının önemine dikkat çekmektedir. Aynı zamanda öğretmenin öğrencilerin çalışmalarında özgün söylemleri betimlemeleri, karşılıklı konuşmaları ve farklılıkları desteklemesi gerektiğini, öğrencileri belirli bir kalıba sokarak sınırlandırmaktan kesinlikle kaçınması gerektiğinin de altını çizmektedir. Yaratıcı yazma çalışmalarının değerlendirilmesinde de ürün temelli değerlendirmeden çok süreç temelli değerlendirmeye önem verilmesi gerektiğini vurgulayan Öztürk (2007) öğrencinin süreçte ne kadar istekli, sabırlı ve ne kadar zaman ayırdığının en önemli etkenler olduğunu vurgulamaktadır. Bu nedenle öğrencinin ortaya çıkardığı ürünün değerlendirildiği kadar süreç içerisinde her öğrencinin ayrı ayrı gösterdiği performansının önem kazandığını vurgulamaktadır. Aynı zamanda değerlendirmede öğrencilerin bireysel gelişim farklılıklarının da ayrıca göz önünde bulundurulması gereken hususlardan olduğuna dikkat çekmektedir. Öğrencilerin yaratıcı yazma için yeterli zaman ayırmaları da ayrıca önemlidir. Schrecengost (2001) öğretmenlerin müfredatları yetiştirme endişesi içerisinde yaratıcı yazma çalışmalarına yeterli zamanı ve önemi veremediklerini belirtmektedir. Aynı zamanda yaratıcı yazma çalışmalarının sadece belli zamanda kazandırılabilecek bir beceri olmadığını günlük sınıf uygulamalarında rutin olarak çalışmalara dâhil edilmesinin önemi vurgulanmaktadır (Akt. 
Öztürk, 2019). Bununla birlikte öğretmenlerin değerlendirme süreçlerinde öğrencilerin biçim, noktalama imla gibi mekanik beceriler üzerinde çok fazla durarak öğrencilerin endişeye kapılmalarına sebebiyet vermeleri aynı zamanda seçilmiş olan konu hakkında öğrencilerin yeterli düşünceye ya da kelime bilgisine sahip olmamasının yazmaya karşı olumsuz tutum geliştirmesine sebebiyet verdiği belirtilmektedir. Bu nedenle özellikle ilkokul çağındaki 9-10 yaşlarındaki çocukların gelişimlerinin dikkate alınarak ilgi duydukları konularda yazma çalışmaları yapılmasının ve yazma esnasında baskıcı bir tutum içerisinde olunmamasının önemi ortaya çıkmaktadır.

Temizkan (2011), 5. Sınıf öğrencilerinin yazılı anlatım çalışmalarının yaratıcı yazma becerileri üzerindeki etkisini incelediği araştırmasında yazma sürecinde yargılanma korkusu olmadan duygusal ve zihinsel yönden rahat bir sinıf ortamında özgürce yapılan yazma çalışmalarının yaratıcı yazma becerilerini geliştirdiğini ortaya koymuştur. Benzer şekilde Demir (2011) yaptığı araştırmasında ilkokul öğrencilerinin yaratıcı yazma becerileri ile yazma öz yeterlilik algıları ve başarı amaç yönelimleri ilişkisini değerlendirdiği çalışmasında öğrencilerin serbest bırakıldıklarında daha yaratıcı ürünler ortaya çıkardıklarını ve yaratıcı yazma becerileri ile yazma öz yeterlilik algıları arasında olumlu ve anlamlı bir ilişki olduğu sonucuna ulaşmıştır. Susar Kırmızı ve Beydemir (2012) yaptıkları araştırmada 5. Sınıf öğrencilerin yaratıcı yazma yaklaşımının yazı yazmaya ilişkin tutumlara etkisini incelediklerinde yaratıcı yazma üzerine yapılan çalışmaların öğrencilerin yazmaya ilişkin olumlu tutum geliştirmelerinde etkili olduğunu göstermektedir.

\section{Araştırmanın Önemi}

Yukarıda belirtilenler ve literatürdeki bulgular dikkate alındığında öğrencilere yazma becerilerinin kazandırılmasının özellikle küçük yaşlardan itibaren yazmaya karşı olumlu tutum geliştirilmesinde önemli olduğunu göstermektedir. Bu noktada da öğretmenlere büyük sorumluluklar düşmektedir. Öncelikle öğrencilerin düşüncelerini mantıksal bir bütünlük içinde yazmalarını sağlamalıdırlar. Bununla birlikte farklı düşünmeye yönlendiren ifadelere, neden-sonuç ilişkileri kurmaya, sınıflandırmaya, karşılaştırma, özetleme ve değerlendirme gibi zihinsel becerileri geliştirici ve anlamayı sağlayıcı çalışmalara yer verilmesi önemlidir (Özden, 2011). 21. Yy becerileri kapsamında kazandırılması önemli olan yaratıcılık aynı zamanda önemli yaşam becerilerinden biridir. Bu doğrultuda duygu, düşünce ve hayallerin özgürce ifade edilmesinde yaratıcı yazmanın ne kadar önemli olduğu görülmektedir. Ayrıca dört temel dil yeteneğinin kazandırılması için sadece bir yolun öğrenme öğretme yaklaşımı olarak kabul edilmesi mümkün olmamaktadır. Dil öğrenimi doğrusal bir etkinlik olmadığından, değişik öğretim yöntem ve tekniklerinin birlikte ve dengeli olarak yürütülmesi gerekmektedir (MEB, 2019, s. 8). Bu doğrultuda geleneksel yazma çalışmaları yanında özellikle teknolojinin günümüze geldiği noktadan hareketle geliştirilen web 2.0 (Voki, Storybird, Little Bird, Story Book) araçlarının yaratıcı yazma çalışmalarında kullanımı da önem kazanmaktadır. Aynı zamanda iletişim boyutu göz önünde bulundurulduğunda alternatif yazma çalışmalarına imkan tanıyan web 2.0 araçları ile yapılacak yazma etkinliklerinin yazma sürecinin yaratıcılığına yeni boyutlar kazandıracağı düşünülmektedir.

$\mathrm{Bu}$ nedenle araştırmamızda web 2.0 araçları (Voki, Storybird, Little Bird, Story Book) kullanılarak yaptırılan yazma etkinliklerinin dördüncü sınıf öğrencilerinin yazmaya yönelik tutumlarına ve yazma becerilerine etkisinin belirlenmesi amacıyla aşağıdaki alt amaçlara ulaşılmaya çalışılmıştır.

1. Web 2.0 araçları kullanılarak yaptırılan yaratıcı yazma etkinliklerinin dördüncü sınıf öğrencilerinin yazmaya ilişkin tutumlarına etkisi nedir?

2. Web 2.0 araçları kullanılarak yaptırılan yaratıcı yazma etkinliklerinin dördüncü sınıf öğrencilerinin yazma becerilerine etkisi nedir? 


\section{Yöntem}

\section{Araştırma Modeli}

Araştırmada deneysel yöntem kullanılmıştır. Bu yöntemin "ön test-son test tek gruplu deseni”" araştırmanın modelini oluşturmaktadır. Bu desende önce ön test ölçümü yapılır, sonrasında deneysel işlem uygulanır ve en sonunda son test ölçümleri yapılır (Creswell, 2014). Ön test ve son test arasındaki fark bağımsız değişkenin bağımlı değişken üzerindeki etkisini gösterir. Yani grubun ölçme araçlarından aldıkları ön ve son test puanlarının aritmetik ortalaması arasında anlamlı farklılık varsa uygulamanın etkili olduğu kabul edilir (Tekin-İftar, 2012).

Tek gruplu ön test-son test deneysel desen, deneysel desenler arasında en zayıf desenlerden biridir. Ancak yeni bir eğitim modülünün geliştirilip uygulandığı araştırmalarda tek gruplu deneysel desenin tercih edilmesi araştırmanın doğası gereğidir (Creswell, 2014).

\section{Araştırma Grubu}

$\mathrm{Bu}$ çalışmanın örneklemi 2019-2020 eğitim öğretim y1lı güz dönemi Erzurum ili Aşkale ilçesinde bir ilkokulun 4.sınıfında öğrenim gören 28 öğrenciden oluşmaktadır. Örneklem grubu amaçlı örnekleme yöntemi ile oluşturulmuştur.

\section{Veri Toplama Araçları}

Öğrencilerin yazmaya yönelik tutumları Susar Kırmızı (2009) tarafından geliştirilen Yazı Yazmaya Yönelik Tutum Ölçeği (YAYTÖ) ile belirlenmiştir. Yaratıcı yazma başarısını belirlemek için ise Susar Kırmızı (2011) tarafından geliştirilen Yaratıcı Yazma İçin Değerlendirme Ölçütleri Formu (YIDÖF) kullanılmıştır. Veri toplama araçlarının kullanımı içim gerekli izinler alınmıştır.

\section{Yazı Yazmaya Yönelik Tutum Ölçeği}

Araştırmada öğrencilerin yazma tutumlarına yönelik verilerin elde edilmesi amacıyla Susar Kırmızı (2009) tarafından geliştirilen ve 34 maddeden oluşan 4. ve 5. Sınıflar için Yazmaya Yönelik Tutum Ölçeği (YAYTÖ, 2009) kullanılmıştır. Ölçeğin ön deneme çalışması Konya ve Erzurum illerinin çeşitli resmî ilkokullarının 4. (n=256) sınıflarında, 2019-2020 eğitim öğretim yıl1, güz döneminde gerçekleştirilmiştir. Elde edilen verilerin faktör analizine uygun olup olmadığını belirlemek için KMO değerine bakılmıştır. Ölçeğin KMO değerinin 0,906 olduğu belirlenmiştir. Büyüköztürk (2010) KMO değerinin 0,70 ve üzeri olmasının yeterli olacağını belirtmektedir. Örneklemin faktör analizi için yeterli olduğu görüldükten sonra, verilerin çok değişkenli normal dağılımdan gelip gelmediği Bartlett küresellik testi ile incelenmiştir. Bartlett küresellik testinin sonucu 0,05 düzeyinde anlamlı çıkmıştır ( $p=0,000)$. Verilere uygulanan Bartlett küresellik testi neticesine göre yaklaşık Chi-Square $=3724,251$ olarak bulunmuştur. Her bir öğrencinin ölçekten alabileceği ağırlıklı ham puan en az 34, en çok 170'tir. Toplam puanın yüksek olması, öğrencilerin yazmaya yönelik tutumlarının olumlu olduğunun, düşük olması ise tutumlarının olumsuz olduğunun göstergesi olarak yorumlanmaktadır.

Araştırmanın örnekleminde ölçeğin güvenilir olup olmadığını belirlemek üzere Cronbach Alpha güvenirlik katsayısına bakılmıştır. Cronbach Alpha katsayısı 0,88 olarak belirlenmiştir. Cronbach Alpha katsayısının 0,70 ve üstü olması ölçeğin güvenilirliği için yeterli görülmektedir (Büyüköztürk, 2014).

\section{Yaratıcı Yazma İçin Değerlendirme Ölçütleri (YİDÖF)}

Yaratıcı yazma değerlendirmeleri amacıyla Susar Kırmızı (2011) tarafindan hazırlanan yaratıcı yazma için değerlendirme ölçütleri (YIDÖF) kullanılmıştır. Bu ölçütler veri toplama sürecinde kullanılmadan önce uzman görüşleri alınmış ve ön uygulama yapılmıştır.

YİDÖF'ün yaratıcı yazma ürünlerini ölçüp ölçmediğini belirlemek amacıyla yapılması hedeflenen ön uygulama Erzurum ilinin bir ilkokulunda 4. sınıfta öğrenim gören 70 öğrenci arasından rastgele seçilen 10 ögrenci ile gerçekleştirilmiştir. Ön uygulamadan elde edilen yazılı ürünlere, YİDÖF'te belirlenen altı ölçüt doğrultusunda puanlar verilmiştir. 
Araştırmacılar tarafından verilen puanların tutarlığının anlaşılması için bir başka uzmandan yardım alınmıştır. Ön uygulamada, araştırmacıların ve uzmanın verdiği puanların görüş birliği yüzdesine bakılmıştır. Verilen puanların güvenirlik değeri birinci ölçüt için 0,85 ; ikinci ölçüt için 0,78 ; üçüncü ölçüt için 0,73 ; dördüncü ölçüt için 0,87 ; beşinci ölçüt için 0,82 ; altınc1 ölçüt için ise 0,89 olarak tespit edilmiştir. Güvenirlik puanlarının 0,70 'in üzerinde çıkması, ölçütlerin değerlendiriciler arasında güvenilirliği sağladığı (Miles \& Huberman, 1994) şeklinde yorumlanabilir.

Belirlenen değerlendirme ölçütleri şunlardır:

1. ÖLÇÜT: Yazının içeriğinin, alışılmışın dışında belli başlı bir yenilik ya da yenilikler içermesi (20 puan).

2. ÖLÇÜT: Yazıda bilinen bir öğenin yeni bir biçimde ifade edilmesi (20 puan).

3. ÖLÇÜT: Yazıda özgün benzetme/benzetmelerin yer alması (15 puan).

4. ÖLÇÜT: Yazıda yer alan yeni fikirlerin anlaşır bir şekilde açılanması (10).

5. ÖLÇÜT: Yazıdaki duygu ve fikirlerin etkili ve akıcı bir şekilde ortaya konulması (20 puan).

6. ÖLÇÜT: Yazıya uygun bir başlık verilmesi (15 puan)

\section{Uygulama, Verilerin Toplanması ve Çözümlenmesi}

Çalışma 2019-2020 eğitim öğretim yılı güz döneminde web 2.0 araçları ile yaratıcı yazarlık etkinlikler adıyla araştırmacının kendi sınıfında serbest etkinlikler dersinde haftada 2 ders olarak planlanıp 12 hafta ( 24 ders) sürmüştür. Öncelikle araştırma grubuna Yazmaya Yönelik Tutum ölçeği ve çalışmanın sonunda yazılması planlanan "Pencereden dışarı baktınız ve ăgaçların kuruduğunu, bitkilerin susuzluktan solduğunu ve çevredeki canlıların nefes almakta güçlük çektiklerini gözlemlediniz. Gelecekte olacaklar hakkinda bir hikâye oluşturunuz." tamamlama metni üzerinde Yaratıcı Yazma için Değerlendirme Ölçütleri kullanılarak ön testler uygulanmıştır.

Ön testler uygulandıktan sonra çalışma grubundaki öğrencilerle ilk iki hafta yaratıcı yazmaya hazırlık çalışmaları yapılmıştır. Bu çalışmalar içerisinde öncelikle öğrencilerin kendilerini rahat ifade edebilecekleri güven ortamı oluşturulmuştur. Sınıfta güven ortamının oluşması için yaratıcı drama etkinlikleri yapılmıştır. Drama ortamı öğrencilerin not kaygısından uzak olmaları, güven duygusunun oluşturulmasını kolaylaştırmıştır. Böylece öğrencilerin duyuşsal ve bilişsel olarak yazı yazmaya hazır hale gelmeleri sağlanmıştır.

Yaratıcı yazma hazıllık aşamasının ardından çalışma grubuyla yazarlık etkinliklerine başlanılmıştır. $\mathrm{Bu}$ süreçte, etkinlikler sonrasında özendirici, isteklendirici ve övgü içeren tarzda geri bildirimler verilmiştir. Her etkinlik sonrasında yazılan metinler web 2.0 araçlarına (Voki, Storybird, Little Bird, Story Book) aktarılarak öğrencilere farklı yollarla kendini ifade etme şansı tanınmıştır. Web 2.0 araçları ile oluşturdukları metinlerin sergilenmesi veya kitap olarak basılı hale getirilmesi öğrencilerin yazı yazmaya olan ilgilerini artırarak süreçte devamlılık sağlamıştır.

12 haftalık çalı̧̧ma sonrasında çalışma grubuna son testler uygulanmıştır. Testlerden elde edilen veriler SPSS-20 programı kullanılarak ilişkili örneklemler için T-testi (Paired Samples T-Test) ile analiz edilmiştir. İlişkili örneklemler için T-testi bir deneysel işlemin öncesi ve sonrasında bağımlı değişkene ilişkin ölçümleri alındığında hedeflenen değişimin anlamlı olup olmadığını belirler (Büyüköztürk, 2014). Karşılaştırılmalarda anlamlılık düzeyi 0,05 olarak alınmıştır.

\section{Bulgular}

Bu bölümde alt problemler doğrultusunda elde edilen bulgular sırasıyla aktarılmıştır.

Yazmaya Yönelik Tutum Ölçeğinden Elde Edilen Bulgular

Çalışma grubunun deneysel çalışma sonrasında yazmaya yönelik tutumlarının ön test ve son test puanları arasında anlamlı bir fark olup olmadığını belirlemek amacıyla yapılan analizlerin sonuçları Tablo 1'de sunulmaktadır. 
Tablo 1. Yazmaya Yönelik Tutum Ön test ve Son test Puanları

\begin{tabular}{|l|c|c|c|c|c|c|}
\hline & N & Ortalama & S & Sd & T değeri & P \\
\cline { 1 - 5 } Ön Test & 28 & 127,0357 & 36,02929 & \multirow{2}{*}{27} & 2,87 & 0,008 \\
\cline { 1 - 3 } Son Test & 28 & 152,8214 & 25,73232 & & & \\
\hline
\end{tabular}

Tablo 1 incelendiğinde çalışma grubunun yazmaya yönelik tutumlarının ön test ve son test puanları arasında $(\mathrm{t}(27): 2,87$ ve $\mathrm{p}<0,05)$ anlamlı bir fark olduğu görülmektedir. Bu sonuca göre çalışma grubu ile yapılan Web 2.0 araçları ile yaratıcı yazma etkinlikleri bu öğrencilerin yazma tutumlarını olumlu olarak anlamlı derecede etkilediği söylenebilir.

\section{Yaratıcı Yazma Başarısı Açısından Elde Edilen Bulgular}

Çalışma grubunun deneysel çalışma sonrasına yaratıcı yazma başarılarının ön test ve son test puanları arasında anlamlı bir fark olup olmadığını belirlemek amacıyla yapılan analizlerin sonuçları Tablo 2'de sunulmuştur.

Tablo 2. Yaratıcı Yazma Başarısı Ön test ve Son test Puanları

\begin{tabular}{|l|c|c|c|c|c|c|}
\hline & N & Ortalama & S & Sd & T de ğeri & P \\
\cline { 1 - 5 } Ön Test & 28 & 51,9643 & 11,88987 & 27 & 7,46 & 0,000 \\
\cline { 1 - 4 } Son Test & 28 & 72,2857 & 11,91904 & & & \\
\hline
\end{tabular}

Tablo 2 incelendiğinde çalışma grubunun yaratıcı yazma başarılarının ön test ve son test puanları arasında (t(27): 7,46 ve $\mathrm{p}<0,05)$ anlamlı bir fark olduğu görülmektedir. Bu sonuca göre çalışma grubu ile yapılan Web 2.0 araçları ile yaratıcı yazma etkinlikleri bu öğrencilerin yaratıcı yazma başarılarını anlamlı derecede etkilediği söylenebilir. Şekil 1'de çalışma grubundaki öğrencilerin ön test ve Şekil 2'de ise son test yaratıcı yazma metinlerine örnekler verilmiştir. 




Şekil 1. Ön test metinleri

Ön test örnek metinleri incelendiğinde uygun başlıklar konulmadı̆̆ı, yazılarda özgün benzetme ve betimlemelerin yer almadığı, yaratıcı olay örgülerine yer verilmediği, yazıdaki duygu ve fikirlerin daha sade ve basit cümlelerle ifade edildiği görülmektedir.
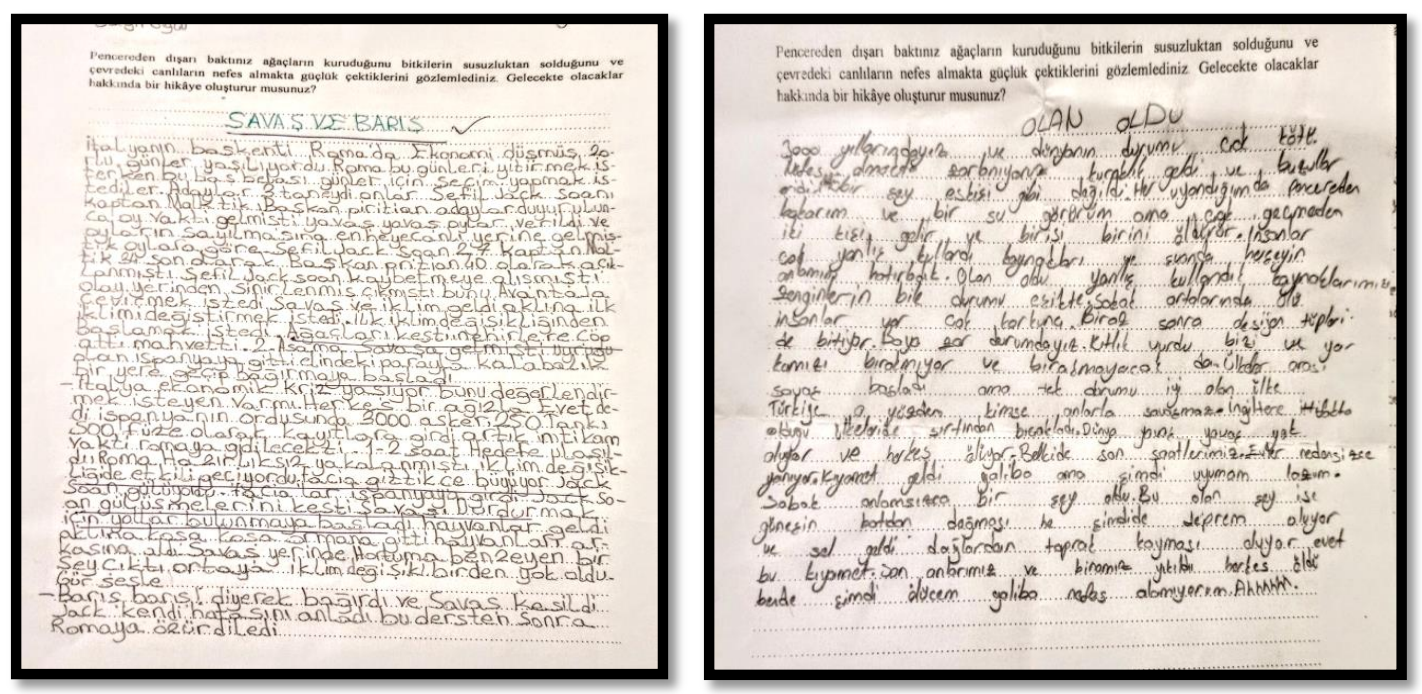


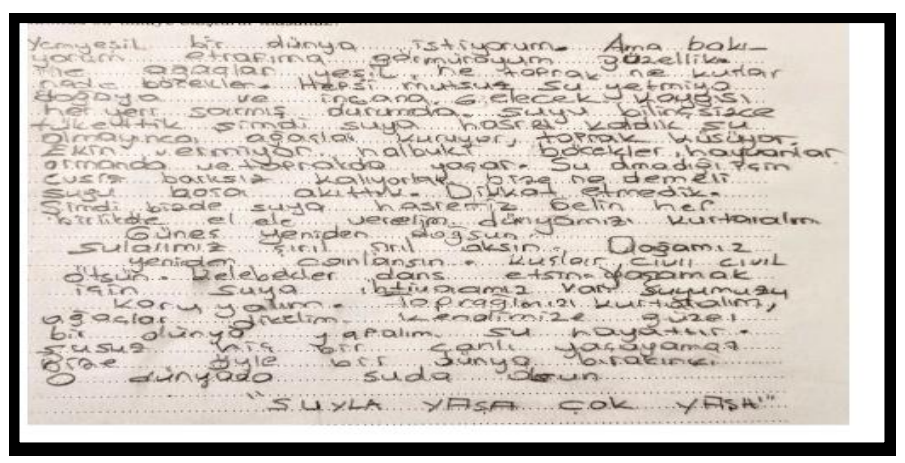

Şekil 2. Son Test Metinleri

Son test örnek metinleri incelendiğinde metinlere uygun ve yaratıcı başlıklar konulduğu, duygu ve fikirlerin daha özgün ve akıcı cümlelerle ifade edildiği, benzetme ve betimlemelerin daha yaratıcı ifadelerle yapıldığı, konunun farklı benzetmelerle yeni bir biçimde ifade edildiği görülmektedir.

\section{Sonuç ve Tartışma}

Web 2.0 araçları ile yapılan yaratıcı yazma etkinliklerinin 4. sınıf öğrencilerinin yazma tutumuna ve yaratıcı yazma becerilerine etkisinin incelendiği araştırmada şu sonuçlar tespit edilmiștir:

Web 2.0 araçları (Voki, Storybird, Little Bird, Story Book) kullanılarak yaratıcı yazma uygulamalarının gerçekleştirildiği çalışma grubu öğrencilerinin yazmaya yönelik tutumlarının yaratıcı yazma etkinliklerine başlamadan önceki tutumları ile karşılaştırıldığında ön test ve son test puanları arasında anlamlı farklılık göstermektedir (t(27): 2,87 ve $\mathrm{p}<0,05$ ). Türkçe derslerinde web 2.0 araçlarının kullanılması ile uygulanan yaratıcı yazma etkinlikleri öğrencilerin yazmaya karşı tutumlarında anlamlı derecede gelişme sağlamıştır. Araştırmanın birinci alt problemine ilişkin sonuçlar, öğrencilerin yazmaya yönelik tutumlarının web 2.0 araçları kullanılarak gerçekleştirilen yaratıcı yazma çalışmaları ile olumlu yönde değiştiğini ortaya koymaktadır. Aynı zamanda interaktif eğitim ortamı firsatının da sunulduğu web 2.0 araçlarının yazmaya yönelik ilgiyi arttırdığı ve yazmayı gerektiren tüm etkinliklerde kullanılmak istendiği sonucuna ulaşılmıştır. Yaratıcı yazma etkinlikleri ile Türkçe derslerini gerçekleştiren çalışma grubunun yazma çalışmalarına karşı daha ilgili, istekli ve olumlu yaklaşmaları yaratıcı yazma çalışmalarının öğrencilerin yazmaya karşı tutumlarını etkilemede önemli ölçüde katkısı olduğunu göstermektedir. Yaratıcı yazma yaklaşımına dayalı etkinliklerle öğretim gören çalışma grubunun yazmaya yönelik tutumlarının, ön test sonuçlarına göre olumlu yönde değişim göstermesi Türkçe derslerinde web 2.0 araçlarının dâhil edildiği yaratıcı yazma çalışmalarına önemli ölçüde yer verilmesi gerektiği düşüncesini desteklemektedir. Çalışma grubunun yazmaya yönelik tutumlarının olumlu yönde değişmesinde, kullanılan web 2.0 araçlarının geleneksel yazma materyallerine göre kullanımının kolay olması, küçük yaş grubu öğrencilerin ilgilerini çekecek şekilde eğlenceli olarak tasarlanmış olmaları aynı zamanda öğrencilerin düşüncelerini rahatlıkla ifade edebilecekleri bir alternatif olması gibi hususların etkili olduğu öne sürülebilir. Aynı zamanda sınıfça yapılan yaratıcı yazma etkinliklerinde işbirliği ile yazılı ürünlerin kolaylıkla paylaşılmasına olanak sağlaması öğrencilerin yazmaya yönelik tutumlarını olumlu yönde etkilediği sonucunu ortaya çıkarmaktadır.

Araştırmanın ikinci alt problemine ilişkin on iki haftalık yaratıcı yazma etkinlikleri sonucunda yaratıcı yazma yaklaşımı doğrultusunda öğretim yapan çalışma grubunun yaratıcı yazarlık etkinlikleri uygulamadan önceki ön test puanları ile karşılaştırıldığında ön test ve son test puanları arasında anlamlı bir farkl1lık göstermektedir ( $t(27)$ : 7,46 ve $\mathrm{p}<0,05)$. Bu durum Türkçe dersi programına göre öğretim gören çalışma grubunun web 2.0 araçları ile desteklenen yaratıcı yazarlık etkinlikleri doğrultusunda öğretim gördükten sonra yaratıcı 
yazma başarılarını olumlu yönde geliştirdiği sonucunu ortaya koymuştur. Uygulama öncesi ve uygulama sonrası öğrencilerin yaratıcı yazmaya dayalı ürünleri YİDÖF ölçütlerine göre değerlendirildiğinde aldıkları puanların ortalamalarına bakıldığına olumlu yönde artış olduğu görülmektedir. Bu durum yaratıcı yazma yaklaşımı doğrultusunda web 2.0 araçları ile yapılan öğretimin öğrencilerin yaratıcı yazma başarılarını önemli ölçüde etkilediği sonucunu ortaya koymaktadır. Araştırmanın açık uçlu sorusu olan "Pencereden dışarı baktınız ve ağaçların kuruduğunu, bitkilerin susuzluktan solduğunu ve çevredeki canlıların nefes almakta güçlük çektiklerini gözlemlediniz. Gelecekte olacaklar hakkında bir hikâye oluşturunuz" tamamlama metnine yönelik yazılan yaratıcı yazma ürünleri değerlendirildiğinde daha özgün mekân, olay, karakter betimlemelerine yer verdikleri ve daha fazla yaratıcı unsurlar içerdiği görülmüştür. Aynı zamanda kullandıkları dil ve üslup açısından da ayırt edici özelliklerin ortaya koyulduğu belirlenmiştir.

Web 2.0 araçları ile yapılan yaratıcı yazma etkinliklerinin 4. sınıf öğrencilerinin yazma tutumuna ve yaratıcı yazma becerilerine etkisinin incelendiği bu araştırma sonucunda yaratıcı yazma etkinlikleri ile gerçekleştirilen Türkçe derslerinin, öğrencilerin yazmaya karş1 tutumlarında ve yaratıcı yazma başarılarında anlamlı ölçüde katkı sağladığı sonucunu ortaya koymuştur.

Araştırmanın sonucunu destekleyen Gökçe (2020), Yegen (2019), Burcu (2019), Abrekoğlu (2019), Beydemir (2010) tarafından yapılan çalışmaların araştırma sonuçlarında da Türkçe öğretiminde gerçekleştirilen yaratıcı yazarlık uygulamalarının öğrencilerin yazmaya yönelik tutumlarında ve yaratıcı yazma başarılarında anlamlı ölçüde değişiklik olduğu ortaya koyulmuştur. Bunun yanı sıra Baş ve Turhan (2017) tarafından gerçekleştirilen araştırmanın sonuçlarında Türkçe öğretiminde web 2.0 araçları kullanılarak uygulanan yazma çalışmalarının öğrencilerin yaratıcı yazma başarılarını arttırdığı ve yazmaya karşı olumlu tutum geliştirdikleri tespit edilmiştir. Susar Kırmızı (2008), Peker (2015), Aykaç (2011) tarafindan yapılan araştırmalarda da yaratıcı yazma uygulamalarının yapıldığı sınıflarda öğretim gören öğrencilerin geleneksel öğretim yapılan sınıflarda öğretim gören öğrencilere göre hem yazmaya karşı olumlu tutum geliştirdikleri hem de yaratıcı yazma becerilerinin olumlu yönde anlamlı farkl11ık gösterdiği sonucunu ortaya koymuştur.

21. yy becerilerinden olan yaratıcılık özellikle küçük yaş bireylerde geliştirilmek istenen bir özelliktir. Okullarda yaratıcılığı geliştirmek adına eğitim öğretim faaliyetlerine yer verilmektedir. Ancak özellikle yaratıcı yazma adına yapılan uygulamalar ve bu uygulamaların öğrencilerin yaratıcılığını ne ölçüde geliştirdiği tartışma konusudur. Belirli kurallar ve kalıplara göre gerçekleştirilmesi beklenen yazma etkinliklerinin öğrencilerin özellikle küçük yaş grubu ögrencilerde yazmaya karşı isteklerini azalttığı, zaman içerisinde olumsuz tutum geliştirdikleri tespit edilmiş olmakla birlikte birçok araştırmada geleneksel öğretim yöntemlerinde değişikliğe gidilmesi yönünde öneriler getirilmiştir (Maden ve Dinç, 2017; Oral, 2014).

\section{6. Öneriler}

Öğrencilerin hem yazı yazmaya karşı olumlu tutum geliştirmeleri hem de yaratıcı yazma becerilerini geliştirebilmek amacıyla interaktif ortamda da rahatlıkla kullanılabilen web 2.0 araçlarından yararlanılabileceği görülmüsstür. Web 2. 0 araçlarının hem öğrencilerin ilgisini çekebilecek hem de eğlenceli ve zihinsel yapılarını destekleyici firsatlar sunması ögrencilerin isteksiz olarak yaklaştıkları yazma etkinliklerine karşı bakış açılarını değiştirmektedir. Deneysel yöntemin kullanıldığı araştırmamızda ön test son test sonuçları ve yazmaya yönelik tutum ölçeği sonucunda elde edilen bulgular birbirini destekler niteliktedir. Elde edilmiş sonuçlar bir bütün olarak değerlendirildiğinde ise kullanılan Voki, Storybird, Little Bird, Story Book gibi web 2.0 araçlarının öğrencilerin yaratıcı yazma becerilerine ve yazmaya karşı olumlu tutum geliştirmelerine önemli ölçüde katkı sağladığ1 görülmektedir. Bu çalışmada araştırmacılardan biri aynı zamanda uygulamanın yapıldığı sınıfın öğretmenidir. Sonuç olarak öğrenciyi merkeze alan, yaratıcılık unsurlarını içeren, yaparak yaşayarak öğrenmeye olanak sağlayan, işbirlikçi, paylaşımlı öğrenmeyi destekleyen, öğretirken eğlendiren web 2.0 
araçlarının yaratıcı yazma becerilerinin geliştirilmesinde Türkçe derslerinde etkili bir alternatif olacağı, yaratıcı yazma uygulamalarında bu araçların kullanımına rahatlıkla yer verilebileceği belirlenmiştir.

Yapılan bu araştırmada çalışma grubu tek bir okuldan seçilmiş olup on iki haftalık bir uygulama sürecini içermektedir. On iki haftalık bir çalışmadan daha kapsamlı ve uzun süreçli çalışmalar farklı sınıf düzeylerinde de gerçekleştirilebilirse daha ayrıntılı ve farklı yaş grubu öğrenciler üzerindeki etkisi de belirlenebilir.

Yaratıcı yazmaya yönelik yapılan yazma etkinliklerinde uygulanan yöntem ve tekniklerden daha farklı yöntem ve tekniklerle çalışmanın gerçekleştirilmesi öğrencilerin yazmaya yönelik tutumlarının olumlu yönde daha da iyileşmesine, yazmaya karşı daha istekli ve ilgili olmalarına olanak sağlayabilir.

$\mathrm{Bu}$ araştırma yaratıcı yazma yaklaşımı doğrultusunda yapılan etkinliklerin kullanılan web 2.0 araçlarının yazma becerisine etkisini ortaya koymuştur. Kullanılabilecek farklı web 2.0 araçları ile farklı çalışmalar yapılabilir.

Aynı zamanda araştırma sonucunda elde edilen veriler web 2. 0 araçlarının kullanılarak yaratıcı yazma etkinlikleriyle öğretim yapılması öğrencilerin yaratıcı yazma başarılarını olumlu yönde arttırmıştır. Yaratıcı yazma etkinlikleri yapılmadan önce elde edilen veriler Türkçe öğretim programında yer alan etkinliklerin yaratıcı yazmaya karşı yetersiz olduğunu göstermektedir. $\mathrm{Bu}$ doğrultuda öğrencilerin yazmaya karşı ilgilerini, isteklerini arttırıcı, yaratıcı yazma becerilerini geliştirici etkinliklere Türkçe öğretim programında yer verilmesi sağlanabilir.

\section{Kaynakça}

Abrekoğlu, B.İ. (2019). Yaratıcı dramanın yaratıcı yazma becerisine ve yazmaya yönelik tutuma etkisi. Yüksek Lisans Tezi, Düzce Üniversitesi, Sosyal Bilimler Enstitüsü, Düzce.

Akyol, H. (2012). Türkçe ögrretim yöntemleri. Ankara: Pegem Akademi.

Akyol, H.(2018). Türkçe ilk okuma yazma ögretimi. Ankara: PegemA Yayınc1lık.

Aykaç, M. (2011). Türkçe öğretiminde çocuk edebiyatı metinleriyle kurgulanan yaratıcı drama etkinliklerinin anlatma becerilerine etkisi. Yayımlanmamış Doktora Tezi, Ankara Üniversitesi Eğitim Bilimleri Enstitüsü, Ankara.

Baş, B. ve Turhan, O.(2017). Yabanc1lara Türkçe öğretiminde yazma becerisine yönelik web 2.0 araçları: Poll Everywhere Örneği. Mersin Üniversitesi Eğitim Fakültesi Dergisi, 2017; 13(3): 1233-1248

Beydemir, A. (2010). İlköğretim 5. sınıf Türkçe dersinde yaratıcı yazma yaklaşımının yazmaya yönelik tutumlara, yaratıcı yazma ve yazma erişisine etkisi. Yüksek Lisans Tezi, Pamukkale Üniversitesi, Sosyal Bilimler Enstitüsü, Denizli.

Brookes, I. \& Marshall, D.(2004), Good writing guide. New York: Harap Publishers Ltd.

Büyüköztürk, Ş. (2014). Sosyal bilimle için veri analizi el kitabı. (14. Baskı). Ankara: Pegem Akademi Yayınevi

Coşkun, E. (2009). Yazma eğitimi. A. Kırkkılıç, H. Akyol (ed.) İlköğretimde Türkçe ögretimi. (2. Baskı s.49-91) Ankara: PegemA Yayıncılık. 
Creswell, J.W. (2014). Educational research: planning, condacting, and evaluating quantitative and qualitative research (4nd ed.). Upper Saddle River, New Jersey, Pearson Education, Inc.

Creswell, J.W. (2008). Reresarch design. Qualitative, quantitative, and mixed methods approaches. SAGE Publications, Thousand Oaks, CA.

Demir, T. (2011). İlköğretim ögrrencilerinin yaratıcı yazma becerileri ile yazma öz yeterlik algısı ve başarı amaç yönelimi türleri ilişkisinin değerlendirilmesi. Yayımlanmamış Doktora Tezi. Gazi Üniversitesi, Eğitim Bilimleri Enstitüsü, Ankara.

Gökçe, A. (2020). İlkokul dördüncü sınıf Türkçe dersinde yaratıcı yazma uygulamalarının ögrencilerin Türkçe dersi tutumu, yazma tutumu ve yaratıcı yazma becerileri üzerine etkisi. Yüksek Lisans Tezi, Bozok Üniversitesi, Sosyal Bilimler Enstitüsü, Yozgat.

Gündüz, O., \& Şimşek, T. (2011). Anlatma teknikleri 2 uygulamalı yazma eğitimi. Ankara: Grafiker.

Güneş, F. (2017). Türkçe öğretimi yaklaşımlar ve modeller. Ankara: Pegem Akademi

Maden, S. ve Dinç, A. (2017). Drama yönteminin Türkçe öğretiminde kullanımının başarı ve kalıcılık üzerine etkisi. Amasya Üniversitesi Ĕğitim Fakültesi Dergisi, 6(2): 454-500

Miles, M. \& Huberman, M. (1994). Qualitative data analysis. (2. Baskı). USA: Sage Publications.

Milli Eğitim Bakanlığı, (2019). Türkçe Dersi Öğretim Programı (İlkokul ve Ortaokul 1, 2, 3, 4, 5, 6, 7 ve 8. Sinıflar). Devlet Kitapları Müdürlüğü Basım Evi.

Oral, G. (2014). Yine yazı yazıyoruz. Ankara: Pegem Akademi Yayıncılık.

Özden, Y. (2011). Öğrenme ve Öğretme. Pegem Akademi.

Öztürk, E. (2007), İlköğretim beşinci sınıf ögrencilerinin yaratıcı yazma becerilerinin değerlendirilmesi. Yayınlanmamış Doktora Tezi, Gazi Üniversitesi Eğitim Bilimleri Enstitüsü, Ankara.

Öztürk, E. (2019). Yaratıcı yazı yazmanın öğretimi. H.Akyol ve M.Yıldız (Ed.) Kuramdan uygulamaya yazma eğitimi. (1. Baskı 216-240) Ankara: PegemA Yayıncılık.

Peker, Ş. (2015). Yazıl anlatım becerilerinin geliştirilmesinde yaratıcı drama tekniklerinden özel mülkiyet tekniğinin yaratıcı yazma yaklaşımı ile karşılaştırılması. Yayınlanmış Yüksek Lisans Tezi, Ankara Üniversitesi Eğitim Bilimleri Enstitüsü, Ankara.

Susar Kırmızı, F. (2008). Türkçe dersinde yaratıcı drama yönteminin yaratıcı yazma başarısına etkisi ve anlatım ürünlerinin değerlendirilmesi. Ankara Üniversitesi Eğitim Bilimleri Fakültesi Dergisi, 41, Özel say1, 251-275.

Susar Kırmızı, F. (2009). Türkçe dersinde yaratıcı drama yöntemine dayalı yaratıcı yazma çalışmalarının yazmaya yönelik tutuma etkisi. Yaratıcı Drama Dergisi, 4 (7), 51-67. 
Susar Kırmızı, F. (2011), Yaratıcı yazma ürünlerinin bazı ölçütler açısından değerlendirilmesine ilişkin nitel bir çalışma. Dil Dergisi, 151, 22-35.

Susar Kırmızı, F. (2015). Yaratıcı drama ve yaratıcı yazma uygulamalarının yaratıcı yazma başarısına etkisi. Eğitim ve Bilim, 40 (181), 93-115. http://dx.doi.org/10. 15390/EB.2015.4552

Susar Kırmızı, F., ve Beydemir, A. (2012). İlköğretim 5. sınıf Türkçe dersinde yaratıcı yazma yaklaşımının yazmaya yönelik tutumlara etkisi. Ahi Evran Üniversitesi, Kırş̧ehir Ĕgitim Fakültesi Dergisi, 13(3), 319-337.

Tekin-İftar, E. (2012). Tek-denekli araştırmalar ve temel kavramlar. E. Tekin-İftar (Ed.), Eğitim ve davranış bilimlerinde tek-denekli araştırmalar. Ankara: Türk Psikologlar Derneği Yayınları.

Temizkan, M. (2011). Yaratıcı yazma etkinliklerinin öykü yazma becerisi üzerindeki etkisi. Kuram ve Uygulamada Eğitim Bilimleri, (11), 919-940.

Yegen, G.D. (2019). İlkokul 3. sını öğrencilerinin yaratıcı yazma becerilerinin yaratıcı drama yöntemiyle gelişstirilmesine yönelik bir eylem araştırması. Yüksek Lisans Tezi, Mehmet Akif Ersoy Üniversitesi, Eğitim Bilimleri Enstitüsü, Burdur. 